\title{
Normal and abnormal jaw development of the yolk-sac larva of Atlantic halibut Hippoglossus hippoglossus
}

\author{
C. M. Morrison, C. A. MacDonald \\ Department of Fisheries and Oceans, Biological Sciences Branch, Halifax Laboratory, Halifax, Nova Scotia, Canada B3J 2S7
}

\begin{abstract}
Normal and abnormal jaw development was studied in laboratory-reared halibut larvae by light and electron microscopy. Abrasion of the epidermis of the tail and head with invasion by bacteria and other foreign organisms was common, especially in larvae grown in wells. Mouth and jaw development was often delayed in larvae with eroded tails. Perforation of the oral membrane in larvae without lesions was not seen until $29 \mathrm{~d}$ at $5^{\circ} \mathrm{C}$ (145 degree-days); younger larvae with mouths possessed lesions on the head, which appeared to be associated with premature breakdown of the oral membrane. Many larvae had gaping jaws, a condition which causes major problems in rearing, since these larvae cannot close their jaws to feed. We found that the jaws of these larvae were not disarticulated, but the anterior parts of the ethmoid and Meckel's cartilages were bent apart. This condition appeared to be associated with abrasion of the head, and invasion by foreign organisms.
\end{abstract}

KEY WORDS: Halibut larva Hippoglossus hippoglossus - Jaw development - Gaping jaws - Bacteria . Fungi

\section{INTRODUCTION}

The smallest wild Atlantic halibut Hippoglossus hippoglossus larva ever observed was $11.9 \mathrm{~mm}$ long, and was at the end of the yolk-sac stage, with a functional and well-formed maxillary, premaxillary, and dentary (Haug et al. 1989). However, a complete series of eggs and larvae of wild Pacific halibut Hippoglossus stenolepis, which is closely related (Trumble et al. 1993), has been obtained and described (Thompson \& Van Cleve 1936). Most knowledge of the early development of the Atlantic halibut larva comes from laboratory rearing. Halibut larvae hatch after $18 \mathrm{~d}$ at $5^{\circ} \mathrm{C}$, with no stomodeum and only a rudimentary gut (Lønning et al. 1982, Blaxter et al. 1983, Kjørsvik \& Reiersen 1992). Hatching to end-of-yolk-sac is about $50 \mathrm{~d}$ (Pittman et al. 1990b, Kjørsvik \& Reiersen 1992). Halibut larvae can capture prey at 144 degree-days (Kjørsvik \& Reiersen 1992), but Harboe et al. (1990) observed that the optimal age for first feeding was around 230 degree-days.

The 'gaping jaws' syndrome is a common problem in cultured halibut larvae (Bergh et al. 1989, Pittman et al. 1989, 1990a, b, Jelmert \& Naas 1990, Opstad \& Bergh 1993). In Pittman et al. (1990b) the oral membrane of larvae with gaping jaws was missing, and the cartilages of the jaws appeared to have been 'locked' open, so that the mouths could not be closed voluntarily or by manipulation with forceps. These larvae were in otherwise good condition until yolk sac absorption, when they died because they were unable to feed. Pittman et al. (1989, 1990a) and Bergh et al. (1989) found more jaw deformities at higher $\left(9^{\circ} \mathrm{C}\right)$ than at lower $\left(3\right.$ and $\left.4^{\circ} \mathrm{C}\right)$ temperatures, but according to Jelmert \& Naas (1990) elevated temperatures did not increase the prevalence of deformities. Opstad \& Bergh (1993) found that the percentage of larvae with jaw deformities did not depend on the numbers of bacteria in the incubators; however, most mortalities in incubators with more bacteria occurred before Day 19 at $6.4^{\circ} \mathrm{C}$, before most jaw deformities were evident. Jelmert \& Naas (1990) described the gaping jaws as 'unarticulated'. Pittman et al. (1987) suggested that the oral membrane is necessary for the development of proper articulation in the jaws, and that early degrada- 
tion of the membrane by bacterial or other means may compromise both stomodeum functionality and larval viability.

We undertook this study of the early normal and abnormal development of the jaws because there had been extensive mortalities among larval halibut grown at the St. Andrew's Biological Station, New Brunswick, Canada, and because abnormal jaw development had been identifed as a common abnormality that might be contributing to these mortalities. Halibut larvae are commercially grown in large enclosed incubators or silos (Pittman et al. 1990a, Harboe et al. 1994). However, we followed the example of several researchers who grew halibut larvae in small wells (Jelmert \& Naas 1990, Bergh et al. 1992) or beakers (Kjørsvik \& Reiersen 1992), because this enabled us to grow the larvae in our laboratory, where we do not have silos, and because it is easier to sample the larvae from small containers. We used cartilage staining as well as electron microscopy to provide a more detailed description of jaw development than is presently available, and to attempt to determine why 'gaping jaws' develop.

\section{MATERIALS AND METHODS}

We received 2 groups of fertilized eggs, just prior to hatching, from the St. Andrew's Biological Station. They had been incubated at $5.8^{\circ} \mathrm{C}$, at which temperature they hatch at 12 to $13 \mathrm{~d}$, and, prior to shipment, had been disinfected by immersion for $10 \mathrm{~min}$ in 400 ppm glutaraldehyde in sea water (Harboe et al 1994) that had been UV treated and filtered. Each group was placed in an insulated container containing ice, which was sent by air to Halifax airport, then immediately transported to our laboratory. The eggs were removed from their container in a cold-room at $5^{\circ} \mathrm{C}$, in dim red light. From the first group, 192 eggs and from the second group 384 eggs were placed in 24-well Multiwell tissue culture plates. One egg was put in each well, in about $10 \mathrm{ml}$ of sea water. The egg membranes (we prefer this term to the term 'chorion' because the latter is already used for one of the layers surrounding the mammalian embryo) were removed within $1 \mathrm{~d}$ after hatching, and $5 \mathrm{ml}$ of the sea water was renewed, as described by Jelmert \& Naas (1990). Thirty to thirty-six eggs from the second group were placed in six $1 \mathrm{l}$ beakers containing $500 \mathrm{ml}$ sea water, 5 or 6 eggs in each beaker (since transparent eggs were dropped directly into the beakers using a pipette, it was difficult to be certain of the number). The sea water was UV treated, filtered, then autoclaved. There were some dead embryos in the eggs received in the second group, so as an added precaution salt was added to the sea water used for both the wells and beakers of this group, so that the eggs and developing larvae floated, helping to keep them above any debris in the containers. The salinity of the sea water supplied to our aquarium is about $32 \mathrm{ppt}$, and addition of salt resulted in a salinity of about $35 \mathrm{ppt}$. The larvae were reared at $5^{\circ} \mathrm{C}$ in the dark except for handling, when dim red light was used.

Some eggs from the first group were found to have small white spots on the surface and so were checked for fungi and bacteria by observation of the egg membrane using phase contrast microscopy. In order to identify any pathogenic bacteria, about 20 squashed eggs from each group were plated and cultured at both 10 and $22^{\circ} \mathrm{C}$ on various media: tryptic soy agar (TSA; DIFCO Laboratories, Detroit, MI, USA); TSA supplemented with $2 \%$ salt ${ }_{i}$ TSA supplemented with $2 \%$ salt and $4 \%$ sheep's blood; thiosulphate citric bile sucrose agar (DIFCO Laboratories) supplemented with $2 \%$ salt; and cytophaga agar and cytophaga agar supplemented with $3 \%$ salt (Austin \& Austin 1987). A modified oxidation/fermentation medium (Walters \& Plumb 1978) was used to differentiate pseudomonads. Eggs were also plated on Sabouraud dextrose agar (Unipath Ltd., Basingstoke, Hampshire, UK) made with $50 \%$ sea water, in order to culture any fungi present.

Samples of eggs and larvae were fixed for light and electron microscopy in phosphate buffer at $\mathrm{pH} 7.2 \mathrm{con}$ taining $1 \%$ glutaraldehyde and $4 \%$ formaldehyde, (McDowell 1978). Eggs from both groups were fixed, including some with white spots. Three to seven developing halibut larvae were removed every alternate day from the first group until, at $30 \mathrm{~d}$ posthatch, all larvae were fixed or dead (total of 67 fixed larvae). In the second group, a total of 50 larvae were fixed. Thirtythree larvae were fixed from wells. Twenty-two apparently normal larvae were fixed: 6 at $7 d, 5$ at $14 d, 5$ at $21 \mathrm{~d}, 5$ at $29 \mathrm{~d}$, and the last larva at $31 \mathrm{~d}$. Eleven abnormal larvae that might not have survived much longer were also fixed: 3 at $11 \mathrm{~d}, 3$ at 14 d, 2 at 21 d, and 3 at $24 \mathrm{~d}$. Seventeen larvae were fixed from beakers, the larvae remaining in each beaker being fixed at 7 ( 3 larvae), 14 ( 3 larvae), 21 (3 larvae), and $29 \mathrm{~d}$ (2 larvae). Four larvae remaining in the fifth beaker were fixed at $31 \mathrm{~d}$, and 1 live and 1 moribund larva remaining in the sixth beaker were fixed at $33 \mathrm{~d}$.

It was noted that, especially after the first few days, the larvae became agitated when the Multiwell plates were moved, or when a pipette was introduced to remove a sample. In the first group, therefore, samples were taken from each Multiwell plate in sequence, and the remaining plates were not disturbed. Any dead individuals in the plate from which samples were being taken were removed. Since there were dead embryos in the eggs of the second group on arrival, and a count at $5 \mathrm{~d}$ revealed that only $143(37.2 \%)$ of the 
larvae remained, all dead individuals were removed from all the trays on the fifth day, on sampling days, and once in between sampling days. Also, on the sampling days any debris was removed from the bottoms of the wells and beakers with a Pasteur pipette, and about $40 \%$ of the water was changed.

For light microscopy, we dehydrated specimens in ethanol, then embedded them in JB4 resin, obtained from Marivac, Inc, Halifax. The larvae were serially sectioned in either transverse or longitudinal section, and sections 1 to $2 \mu \mathrm{m}$ in thickness were stained with a 1:50 dilution of $1 \%$ toluidine blue in $1 \%$ sodium borate. We processed specimens for scanning electron microscopy (SEM) by post-fixing them in $1.5 \%$ osmium tetroxide and dehydrating them in ethanol. The samples were critical-point-dried and sputter-coated with gold-palladium. Samples for transmission electron microscopy (TEM) were dehydrated in acetone and embedded in epon/araldite. Sections $0.5 \mu \mathrm{m}$ in thickness were stained in $1 \%$ toluidine blue in $1 \%$ sodium borate for light microscopy, in order to determine that the areas required were in the section; then ultrathin gold and silver sections were prepared and stained in uranyl acetate and lead citrate. We stained whole halibut larvae for cartilage and bone using the same method as for cod larvae (Morrison 1993.)

Photographs of fixed eggs and larvae, and of larvae stained for cartilage and bone, were taken with the Tessovar Zeiss photomacrographic zoom system. A Zeiss photomicroscope and Hitachi scanning and transmission electron microscopes were used for light and electron microscopy. JB4 resin sections of 1 larva were photographed for use in a partial 3-dimensional reconstruction of the cartilages of the head, done on an Interactive Computer Analysis and Reconstruction Workstation (ISG Technologies Inc, Mississauga, ON, Canada).

\section{RESULTS}

\section{Eggs with white spots}

White spots in the first group of eggs were found to be an organism with a radiating pattern of growth on the surface of the yolk, beneath the egg membrane (Figs. $1 \& 2$ ). In the second group there were eggs with dead embryos, which also appeared white. Bacteria were present on the surface of most of the egg membranes in both groups (Fig. 3). Some of these had one end inserted in the pores on the surface of the egg, and some were dividing (Fig. 4). Rod-shaped and more elongate organisms were found in the micropyle and on the egg surface around it, and both regions showed signs of damage (Fig. 5). Some of the rod-shaped organisms appeared to be bacteria, and some formed elongate chains; some of the elongate organisms looked like fungal hyphae. Very few bacteria grew on the media inoculated with squashed eggs, and only some Pseudomonas sp. were noted. None of the following fish pathogens were identified: Aeromonas salmonicida, Yersinia ruckeri, Vibrio salmonicida, $V$. anguillarum types I and II, Cytophaga sp. and Flexibacter $\mathrm{sp}$

\section{Larvae}

There was $65.1 \%$ mortality over $30 \mathrm{~d}$ in the first group. In the second group there was $91.4 \%$ mortality over $31 \mathrm{~d}$ in wells, and 43.3 to $52.8 \%$ (depending on whether there were originally 5 or 6 eggs in each beaker) during $33 \mathrm{~d}$ in beakers. Dead larvae rapidly became covered with bacteria and disintegrated, so the cause of death could not be determined in most cases.

Thirty-eight larvae from the first group were examined. Eleven (28.9\%) were abnormal and 27 appeared to be normal, but 13 of the latter were examined only at the gross level, with a dissecting microscope. Abnormal development was associated with the head or tail. Six of the abnormal larvae had eroded tails, and 1 of these also had gaping jaws. Four other larvae had gaping jaws, and 1 had lesions on the head; so $13.2 \%$ of the larvae examined had gaping jaws.

In the second group, 20 larvae from wells were examined. Fourteen (70\%) were abnormal; 4 had eroded tails, 5 had gaping jaws, 4 had lesions on the head and tail, and 1 had lesions on the head, so $25 \%$ had gaping jaws. Six larvae, 5 of them examined at the gross level only, appeared to be normal. Twelve larvae were examined from beakers. Two $(16.7 \%)$ had gaping jaws; the other 10 examined, 5 only at the gross level, appeared to be normal.

\section{Normal development}

Two cartilages, each representing the fusion of the trabecules, polar cartilages and parachordal plate (McElman \& Balon 1979), were first seen in a $13 \mathrm{~d}$ old larva, and by $14 \mathrm{~d}$ the cartilages had fused anteriorly to form the ethmoid cartilage. At $14 \mathrm{~d}$ there was no indication of the stomodeum, but by $17 \mathrm{~d}$ a region covered by an oral membrane could be distinguished (Fig. 6).

The mouth was still usually closed at $21 \mathrm{~d}$ (Fig. 7) by a thin oral membrane (Fig. 8). In some larvae, the tip of the ethmoid cartilage was bent up. The protractor hyoideus muscle, which is attached to the symphysis of the Meckel's cartilages, was present near the mid-line. The ethmoid and the Meckel's, hyosymplecticum, and 

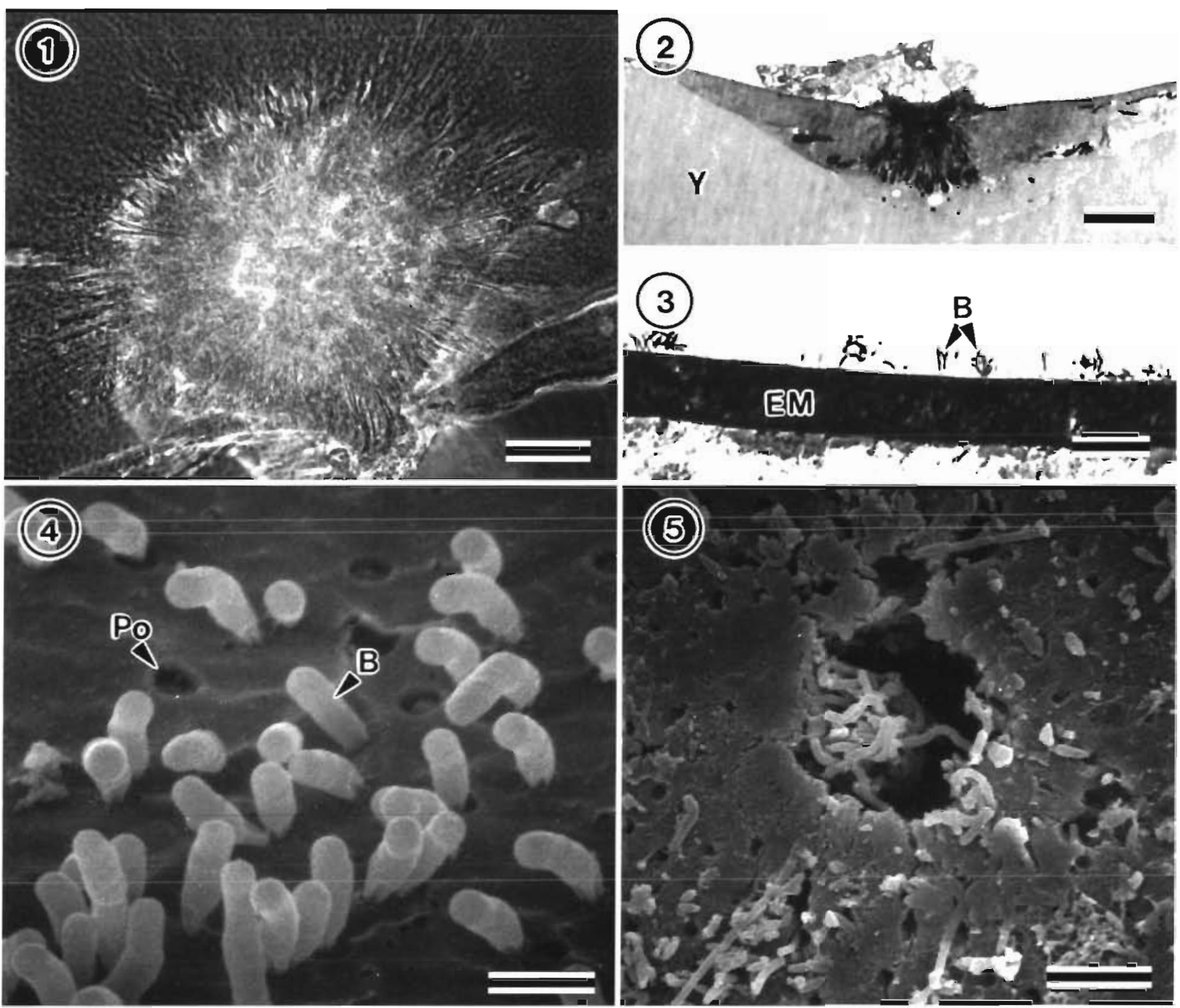

Figs. 1 to 5. Hippoglossus hippoglossus. Egg membrane. Fig. 1. Radiating organism (fungus?) which appeared as white spots on some eggs. Squash preparation of egg; scale bar $=50 \mu \mathrm{m}$. Fig. 2 . Organism causing white spot on egg, invading periblast of yolk (Y). JB4 resin, toluidine blue stain; scale bar $=50 \mu \mathrm{m}$. Fiq. 3. Bacteria (B) on surface of egg membrane (EM). JB4 resin, toluidine blue stain; scale bar $=20 \mu \mathrm{m}$. Fig. 4 . Bacteria (B), some dividing, on surface of egg membrane. Several have one end inserted in a pore (Po). SEM; scale bar = 1 m. Fig. 5. Micropyle of egg containing rod-shaped and filamentous organisms, which are also

present on the surrounding egg surface. The rim of the micropyle and the egg surface are damaged. SEM; scale bar = $5 \mu \mathrm{m}$

quadrate cartilages were present but not yet wellarticulated with each other, and the branchial arches were beginning to develop (Fig. 9). One larva was found with the anterior part of the mouth open at $23 \mathrm{~d}$ (Fig. 10). No bacteria were visible externally, but there were small lesions around the mouth. The mouth was still closed laterally, anterior to the angle of the jaw, by a membrane which was only 2 or 3 cells thick (Fig 11). A $27 \mathrm{~d}$ old larva with no lesions was found in which the region covered by the oropharyngeal membrane was indented, but the mouth had not yet formed (Fig. 12). There was a small, circular perforation, with no indica- tion of bacteria or abnormal cells, in the centre of the oral membrane of one 29 d larva (Fig. 13).

\section{Abnormal development}

The cartilages of larvae with eroded tails were not as advanced in their development as those of uninfected larvae, and 2 cartilages which had not yet fused anteriorly were present in 17 and 19 d larvae with damaged tails (Fig 14). One 19 d larva stained for cartilage and bone had gaping jaws (Fig. 15). The cartilages forming 
the ethmoid were not completely fused, and were bent up anteriorly, whereas the anterior symphysis of Meckel's cartilage was bent down. The matrix of the cartilage in both the tip of the ethmoid and symphysis between the Meckel's cartilages was not as dense as in the rest of the cartilage (Fig, 16).

Of the larvae examined at $21 \mathrm{~d}, 7$ appeared to be normal, but 5 had lesions on the head, including 1 with gaping jaws. One had a perforated oral membrane surrounded by degenerating tissues (Fig. 17) containing rod-shaped bacteria of varying sizes (Fig. 18). Another larva had pectoral fins, the margins of which were attached to the body; it also had a lesion on the head (Fig. 19) which consisted of rounded cells. Hyphae-like growths extended from epidermal cells at the edge of the lesion (Fig. 20). The larva with gaping jaws (Fig, 21) had an ethmoid cartilage which bent up anteriorly, and a Meckel's cartilage, the anterior part of which curved down and posteriorly (Fig. 22).

Some 24 d old larvae also had abnormal heads, a few with no mouth development (Fig. 23). They also had eroded tails that were covered with bacteria (Fig. 24). One had gaping jaws, and pectoral fins which had not separated from the body (Fig. 25); bacteria were present in lesions around the mouth. In another larva with a small opening in the oral membrane, the tip of the ethmoid was bent up and Meckel's cartilages were convoluted and pushed backwards, with the anterior symphysis bent down (Figs. $26 \& 27$ ). There were hyphae-like extensions on some of the epidermal cells covering the anterior part of the head, and there were bacteria in lesions which extended from the epidermal surface down into the tissues of the head (Fig. 28). Bacteria were also present in the opening in the oral membrane and in the oral cavity (Fig. 29), and a group of bacteria was eroding cells that were condensing to form Meckel's cartilage (Fig. 30).

A few bacteria were present in small lesions around the mouth of a 25 d larva with gaping jaws, but this larva had no other apparent abnormalities. Bacteria were not evident on the external surface of one $27 \mathrm{~d}$ larva with an opening in the oral membrane, but there were bacteria attached to the epithelium lining the buccal cavity. The epithelial cells contained dense inclusions which may have represented the remains of bacteria (Fig. 31). There were many macrophages in the loose connective tissue of the head, some with lysosomal contents that could have been derived from bacteria. Some flagella were seen among the macrophages (Fig. 32), and the chondrocytes of Meckel's cartilage contained myelin figures (Fig. 33).

Larvae with gaping jaws as well as other abnormalities were found at 29 and $31 \mathrm{~d}$, but no bacteria were evident. Contraction of the protractor hyoideus muscle was evident in one 29 d larva with gaping jaws
(Fig. 34). Up to $33 d$, only cartilage was present in the head. There was no indication of formation of the maxillary or dentary, or of tooth formation.

\section{DISCUSSION}

Bacteria are often associated with fish eggs, and some can damage the egg membrane by exoenzymatic activity, as reported by Bergh et al. (1992). These authors showed that experimental infections of bacteria can result in ulceration of the egg surface and damage to the region around the micropyle. The bacteria found on the halibut eggs in our study, some of which had a similar morphology to the Flexibacter sp. shown in Bergh et al. (1992), did not appear to be causing damage except in the region of the micropyle. The lack of bacterial growth in culture indicates that the glutaraldehyde treatment of the halibut eggs was fairly effective, and the bacteria we saw on eggs may have been dead, and fixed by the glutaraldehyde. However, the presence of viable pseudomonads showed that the eggs were not completely sterile.

The halibut larvae in our study were evidently susceptible to abrasion, especially when confined to wells. This susceptibility would not be an important factor for survival in the normal environment of halibut larvae, which is the open ocean. The presence of pathogenic and opportunistic bacteria on eggs has been shown by Bergh et al. (1992) to be correlated with increased larval mortalities. According to our cultures, known salmonid pathogenic bacteria were not present on the eggs; but because, in most cases, bacteria were found within the tissues of the head when the epidermis had been damaged, the associated bacteria may have been opportunistic pathogens. These bacteria could have been airborne, or have survived either the glutaraldehyde treatment of the eggs or the UV treatment of the sea water.

Both bacteria and ciliates or flagellates (unidentified flagellates were seen in the water from some wells) were evidently able to infiltrate the loosely organised tissues of the head. The hyphae-like processes found on the epidermal surface of larvae could have originated from the radiating organism on the yolk surface of some eggs. Unfortunately we were unable to identify this organism, which we found only in fixed material, so that it could not be cultured. So far we have been unable to find it in eggs fixed for TEM. Eroded tails covered with numerous bacteria have been described by Bergh et al. (1989) and Pittman et al. (1990a), who found that the bacteria were filamentous. In contrast, those we found were mainly rod-shaped.

Our finding that cartilage first appears in the head on Day 13 at $5^{\circ} \mathrm{C}$, or 65 degree-days, is similar to that of 

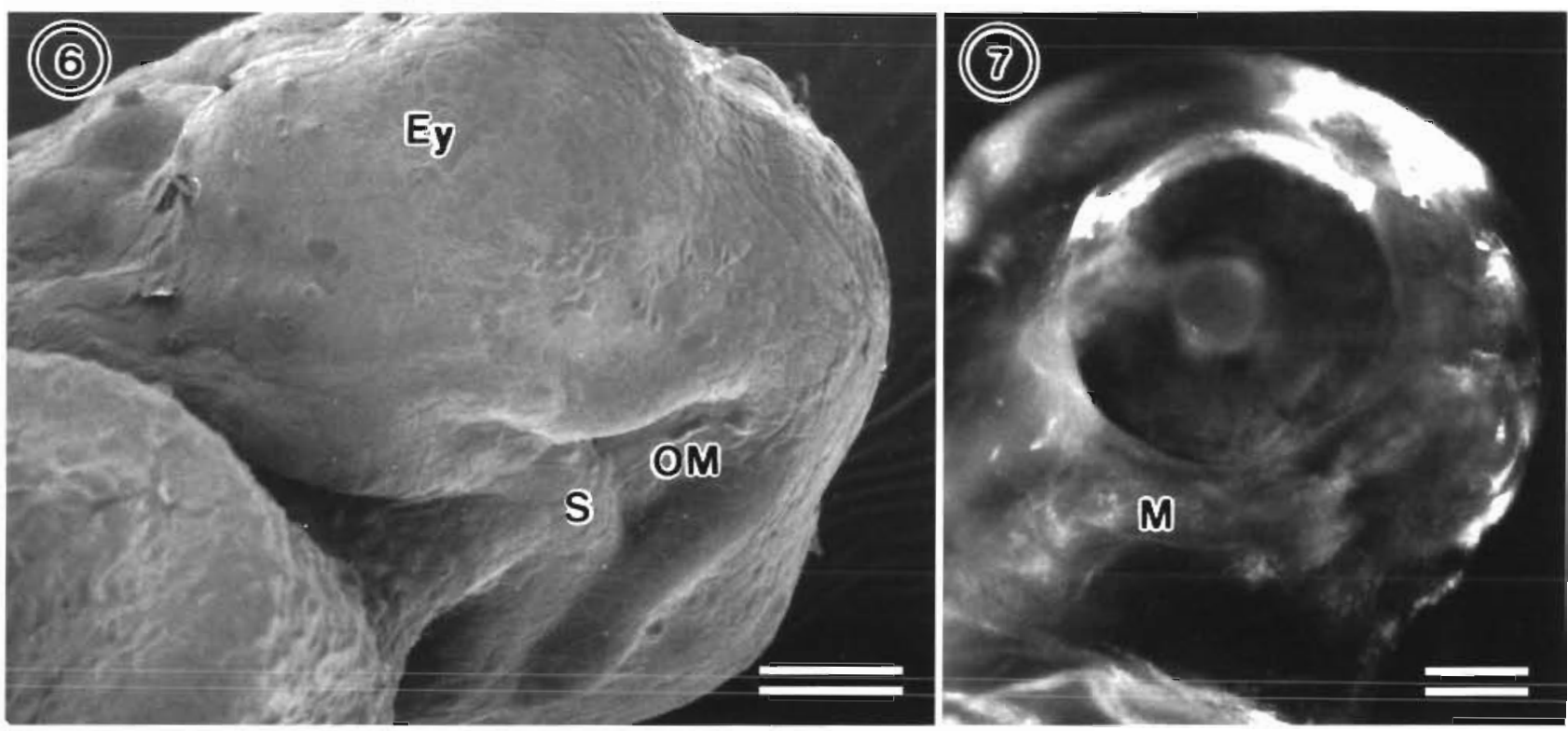

Figs. 6 to 13 (above and on facing page). Hippoglossus hippoglossus. Normal larvae. Fig. 6. Ventral surface of head, with an indented region covered by an oral membrane $(\mathrm{OM})$, where the mouth will form. Posterior to this region is the anterior symph$y$ sis (S) of the Meckel's cartilages. The eye (Ey) is prominent. $17 \mathrm{~d}$, SEM; scale bar $=100 \mu \mathrm{m}$. Fig. 7 The lower jaw is well-formed, with well-defined Meckel's cartilages (M). The mouth is covered by an oral membrane, and the eye is pigmented. $21 \mathrm{~d}$, gross; scale bar $=200 \mu \mathrm{m}$. Fig. 8 . Sagittal section of the anterior part of head, showing the oropharyngeal cavity covered anteriorly by a thin oral membrane $(O M)$. The anterior tip of the ethmoid cartilage (E) is bent up. Meckel's cartilage (M) and the protractor hyoideus muscle $(\mathrm{PH})$ are present. $21 \mathrm{~d}$, JB4 resin, toluidine blue stain; scale bar $=100 \mu \mathrm{m}$. Fig. 9. The ethmoid cartilage (E) is straight anteriorly, and Meckel's cartilages are slightly curved, meeting at an anterior symphysis (S). The hyosymplecticum (Hy) and quadrate (Q) cartilages are present, and the eye (Ey) is pigmented. $21 \mathrm{~d}$, stained for cartilage and bone; scale bar $=200 \mu \mathrm{m}$ Fig. 10. Anterior view of larva with open mouth surrounded by small lesions (Le). $23 \mathrm{~d}$, SEM; scale bar $=1.00 \mu \mathrm{m}$. Fig. 11 Transverse section through oropharyngeal cavily. The tissue layers surrounding the cavity laterally are thin just above Meckel's cartilages (M). 23 d. J84 resin, toluidine blue stain; scale bar $=100 \mu \mathrm{m}$. Fig. 12. Larva with mouth not yet formed. There are several neurumasts ( $\mathrm{Ne}$ ) on the head, and a well-developed olfactory epithelium (OE). $27 \mathrm{~d}$, SEM; scale bar $=150 \mu \mathrm{m}$. Fig. 13. Larva with rounded opening in the oral membrane (OM). There are no lesions on the head. $29 \mathrm{~d}$, SEMi scale bar= $150 \mu \mathrm{m}$

Kjørsvik \& Reiersen (1992), who found that cartilage appeared on Day 12 at $6^{\circ} \mathrm{C}$, or 72 degree-days. Pittman et al. (1990a) found, as we did, that gaping jaws first appeared at $19 \mathrm{~d}$. However, the development of gaping jaws did not involve disarticulation of the joints, as suggested by Pittman et al. (1989), but was caused by the ethmoid and Meckel's cartilages bending apart anteriorly. We found no indication of formation of the maxillary or dentary or of teeth as reported by Pittman et al. (1990b) in 25 d larvae. In some individuals deformities in the head seemed to be linked to failure of the periphery of the pectoral fin to separate from the body. Jelmert \& Naas (1990) also found that gaping jaws were often linked with other deformities.

In apparently normal larvae, the anterior tip of the upper jaw tends to bend up and the lower jaw down, giving a 'pig-like' (Prince 1916) or 'pugged' (Thompson \& Van Cleve 1936) appearance. The anterior tips of the jaw cartilages were pushed further apart in the 'gaping jaw' condition. The highest percentage of larvae with gaping jaws was found in the second group grown in wells in our study, which also had the highest percentage of lesions and mortalities (many individuals with abnormalities probably died before they could be fixed). The jaw cartilages would be pushed apart more easily when the tissues of the anterior surface of the head had deteriorated after abrasion and invasion by foreign organisms. Other authors have found that the frequency of jaw deformities increased when halibut larvae were exposed to physical stress, as they were when confined in wells as in our study; these workers suspected that bacterial infections were the primary cause of these deformities (Harboe et al. 1994). Bacterial invasion of the head tissues of one larva (Figs. 26 to 29) through a break in the epidermal covering and through a small hole in the oral membrane was associated with the anterior parts of the jaw cartilages being pushed apart, although most of the oral membrane was intact. Development of the gaping jaw condition is therefore not dependent on complete breakdown of the oral membrane, as suggested by Pittman et al. (1987), but, since the membrane is thin, it would tend to disintegrate easily after bacterial invasion. Bacteria could also enter the gut through the 


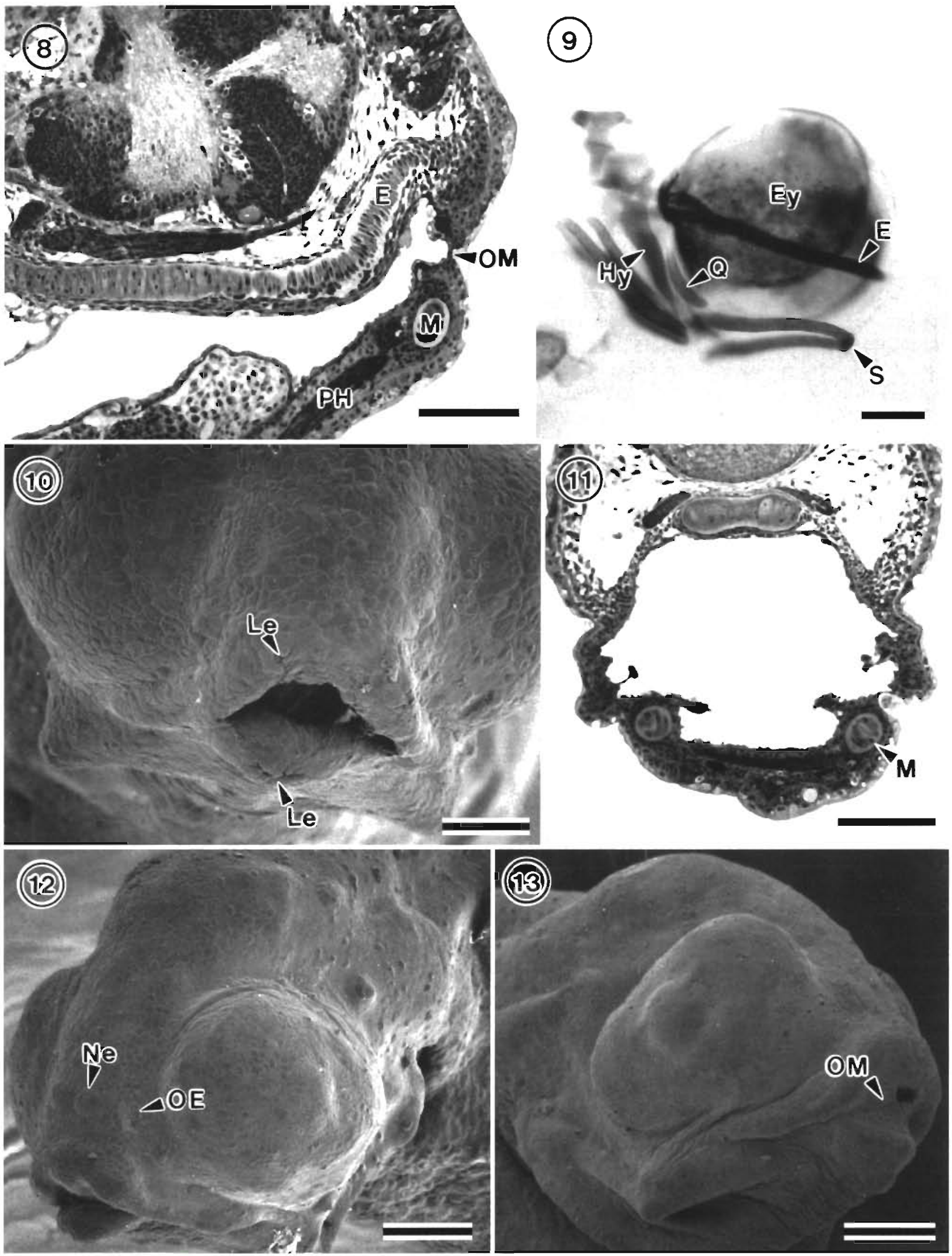


branchial opening, but would infiltrate tissues of the head more easily through breaks in the epidermis than through the epithelium lining the gut. The reduced matrix density of the anterior regions of the ethmoid and Meckel's cartilages would also make it easier for them to be pushed apart in halibut than in cod larvae, where the density of these cartilages is fairly uniform, and gaping jaws have not been described (Morrison 1993). The effect on the anterior symphysis of Meckel's cartilages was more dramatic than that on the anterior part of the ethmoid. The protractor hyoideus muscle normally pulls this symphysis down and back when it contracts, opening the mouth, but when the tissues in the anterior part of the head around the symphysis are weakened, the muscle would be able to pull the symphysis down and back prematurely, before the cartilaginous matrix was properly formed, so that Meckel's cartilages would be bent and unable to return to their normal position.

As reported by Pittman et al. (1989), bacteria were difficult to find on the jaws of larvae once the mouth was gaping, although we were able to find some on degenerating tissues in larvae up to $25 \mathrm{~d}$. The presence of bacteria and apparently flagellated organisms in the head tissues of a $27 \mathrm{~d}$ larva with a mouth indicated that foreign organisms may be present internally, even when they are not externally evident. We found that older larvae possessed macrophages and so would be more able to control infections, but the cartilages of gaping larvae were already deformed at this stage.

The mouth was still closed in one $27 \mathrm{~d}$ old halibut larva without lesions. Perforation of the oral membrane by a rounded opening, which was the method by which the mouth began to form in undamaged cod larvae (Morrison 1993), was not seen until 29 d (145 degreedays). This supports the observations that halibut larvae do not capture food until 144 degree-days (Kjørsvik \& Reiersen 1992), or 157 degree-days (Harboe et al. 1990). Younger larvae with mouths had external lesions, so the oral membrane had probably deteriorated prematurely as a result of abrasion and infection by bacteria or other organisms. Blaxter et al. (1983) found that the mouth formed at $21 \mathrm{~d}$ at $4.7^{\circ} \mathrm{C}$, or 98.7 degree-days, but they stated that the mouth was wide open and could not be closed until after $25 \mathrm{~d}$, so these larvae may have been suffering from gaping jaws.

In cod larvae, the oropharyngeal membrane persists for some time as dorsal and ventral flaps (Morrison 1993), but in halibut larvae the anterior part of the membrane disappeared after it was perforated. How-

Figs. 14 to 34 (next 3 pages). Hippoglossus hippoglossus. Abnormal larvae. Fig. 14. Two cartilages diverge posteriorly to either side of the anterior tup of the notochord (N). $17 \mathrm{~d}$, stained for cartilage and bone; scale bar $=50$ um. Fig. 15. Larva with gaping jaws. The anterior end of the ethmoid $(E)$ is bent up, and the 2 cartilages from which it is derived are visible. The anterior symphysis (S) of Meckel's cartilages is bent down. Cartilage is forming in the gull arches, and there is pigment in the eye (Ey). $19 \mathrm{~d}$, stained for cartilage and bone; scale bar $=200 \mu \mathrm{m}$. Fig. 16. The cartilaginous matrix is less dense at the anterior symphysis (S) between Meckel's cartilages (M), and the anterior tip of ethmoid (E), than in the rest of the cartilage. $19 \mathrm{~d}$, stained for cartilage and bone; scale bar $=60 \mu \mathrm{m}$. Fig. 17. There is an opening in the oral membrane, surrounded by degenerating tissues. $21 \mathrm{~d}, \mathrm{SEM}$; scale bar $=100 \mu \mathrm{m}$. Fig. 18. Bacteria $(B)$ in part of lesion shown in Fig. $17.21 \mathrm{~d}$, SEMi scale bar $=2.5 \mu \mathrm{m}$. Fig. 19. Dorsal view of head with lesions consisting of rounded cells $(R)$. The pectoral fins $(P)$ form ridges on either side of the body. $21 \mathrm{~d}, S E M ;$ scale bar $=100 \mu \mathrm{m}$. Fig. 20. Edge of lesion shown in Fig. 19, at higher magnification. The lesion consists of rounded cells $(R)$, and there are hyphae-like growths $(\mathrm{H})$ on the epithelial cells around it. $21 \mathrm{~d}, \mathrm{SEM}$; scale bar $=10 \mu \mathrm{m}$. Fig. 21 . Larva with lower jaw containing Meckel's cartilage (M) bent down anteriorly. $21 \mathrm{~d}$, gross; scale bar $=200 \mu \mathrm{m}$. Fig. 22. Same specimen as Fig. 21 The anterior tip of the ethmold cartilage is bent up, and Meckel's cartilage in the lower jaw is bent down anteriorly. $21 \mathrm{~d}$, stained for cartilage and bone; scale bar $=200 \mu \mathrm{m}$. Fig. 23. Larva with no mouth development, and eroded tail. $24 \mathrm{~d}, \mathrm{SEM}$; scale bar $=500 \mu \mathrm{m}$. Fig. 24 . Bacteria on eroded tail. $24 \mathrm{~d}$, SEM; scale bar $=5 \mu \mathrm{m}$. Fig. 25. Larva with gaping jaws, lesions on head and pectoral fin (P) which has not separated from the body. $24 \mathrm{~d}, \mathrm{SEM}$; scale bar $=100 \mu \mathrm{m}$. Fig. 26. Anterior tip of ethmoid (E) is bent up, and Meckel's cartilage $(M)$ is pushed back and is bent. The oral membrane (OM) is intact. There are groups of rounded up epidermal cells and macrophages (R) on the anterior surface of the head. $25 \mathrm{~d}$, longitudinal section (LS), JB4 resin, toluidine blue stann; $s c a l e b a r=200 \mu \mathrm{m}$. Fig. 27. Same specimen as Fig. 26. Partial 3-dimensional reconstruction of head cartilages from JB4 resin sections, seen from an antero-lateral view. Meckel's cartilages (M) are convoluted, and the anterior symphysis (S) is bent down. The left eye (Ey), hyosymplecticum $(\mathrm{Hy})$ and quadrate $(\mathrm{Q})$ cartilages are shown, but not those of the right side. Fig. 28. Anterior part of head of specimen shown in Fig. 26. There is a break in the epidermis containing bacteria $(B)$, and the lesion extends into the connective tissue. There are hyphae-like processes $(\mathrm{H})$ on the epidermal cells. $25 \mathrm{~d}$, LS, JB4 resin, toluidine blue stain; $\mathrm{scale}$ bar $=15 \mu \mathrm{m}$. Fig. 29. Oral. region of specimen shown in Fig 26. Bacteria (B) are present in the region of the oral membrane (OM), on the outer epidermal surface and in the oral cavity (O). $25 \mathrm{~d}$, LS, JB4 resin, toluldine blue stain; scale bar $=15 \mu \mathrm{m}$. Fig. 30 . Meckel's cartilage (M) anterior to the oral cavit) $(\mathrm{O})$ of specimen shown in. Fig. 26. A group of bacteria (B) appears to be causing erosion of cells condensing around the cartilage. $25 \mathrm{~d}$, LS, JB4, resin, toluidine blue stain; scale bar = $15 \mu \mathrm{m}$. Fig. 31. Dorsal epithelial lining of oropharyngeal cavity (O) of larva with open mouth. The epithelial cells contain electron-dense inclusions (I), and have bacteria $(B)$ on the surface. There are macrophages (Ma) containing lysosomes (L) in the underlying connective tissue. $27 \mathrm{~d}, \mathrm{TEM}$; Scale bar $=2 \mu \mathrm{m}$. Fig. 32. Macrophages in connective tissue in antenor part of head of same larva shown in Fig. 31, containing electron-dense inclusions (I). A flagellum (F) is present between the cells. $27 \mathrm{~d}$, TEM; scale bar = $1 \mu \mathrm{m}$. Fig. 33. Meckel's cartilage of same larva shown in Figs 31 \& 32. Myelin figures (My) are present in the chondrocytes. Nu is nucleus of a chondrocyte. $27 \mathrm{~d}$, $T E M$, scale bar $=2 \mu \mathrm{m}$. Fig. 34 . Ventral view of head of larva with gaping jaws; the protractor hyoideus muscle (PH) is contracted. 


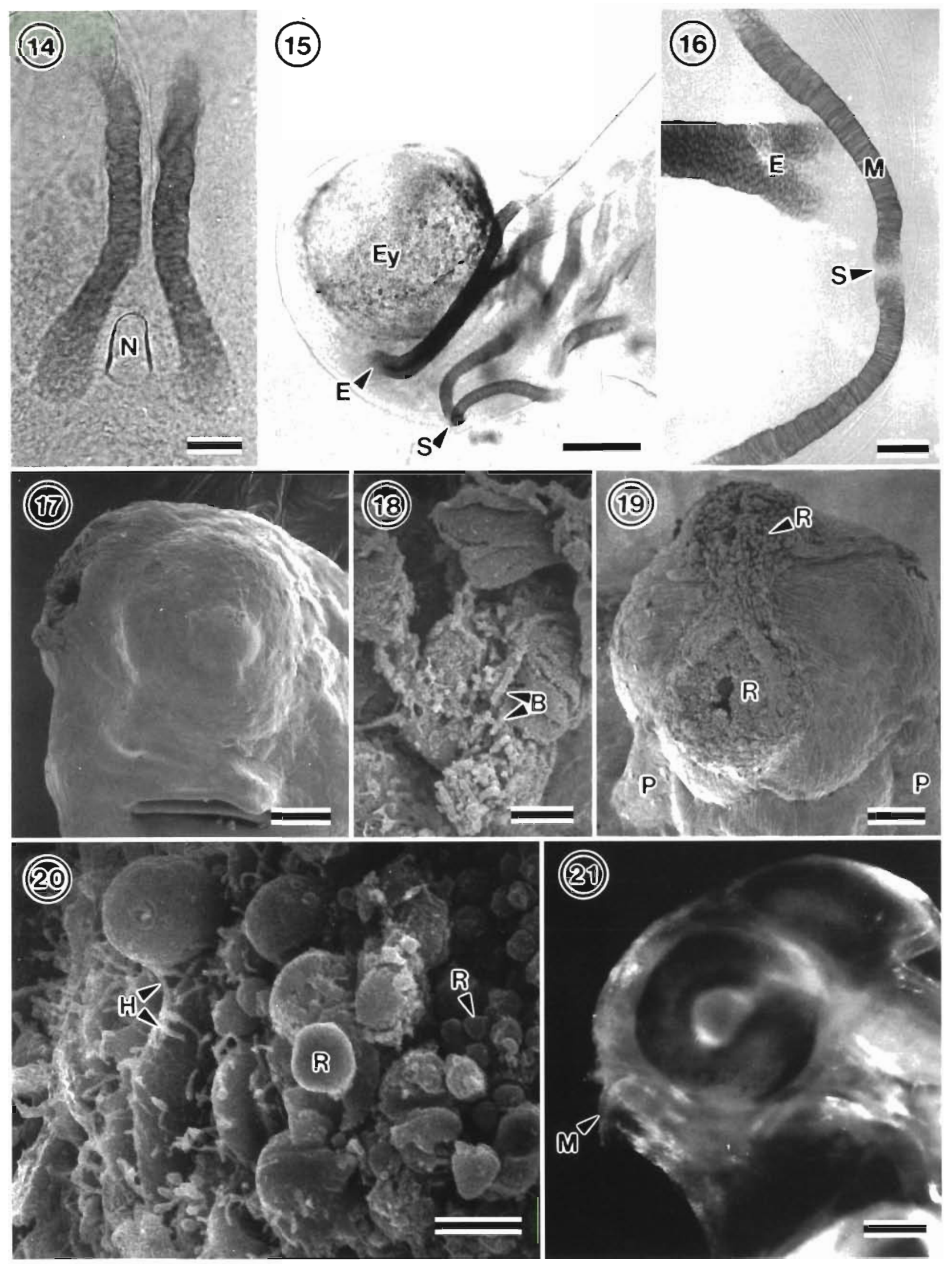



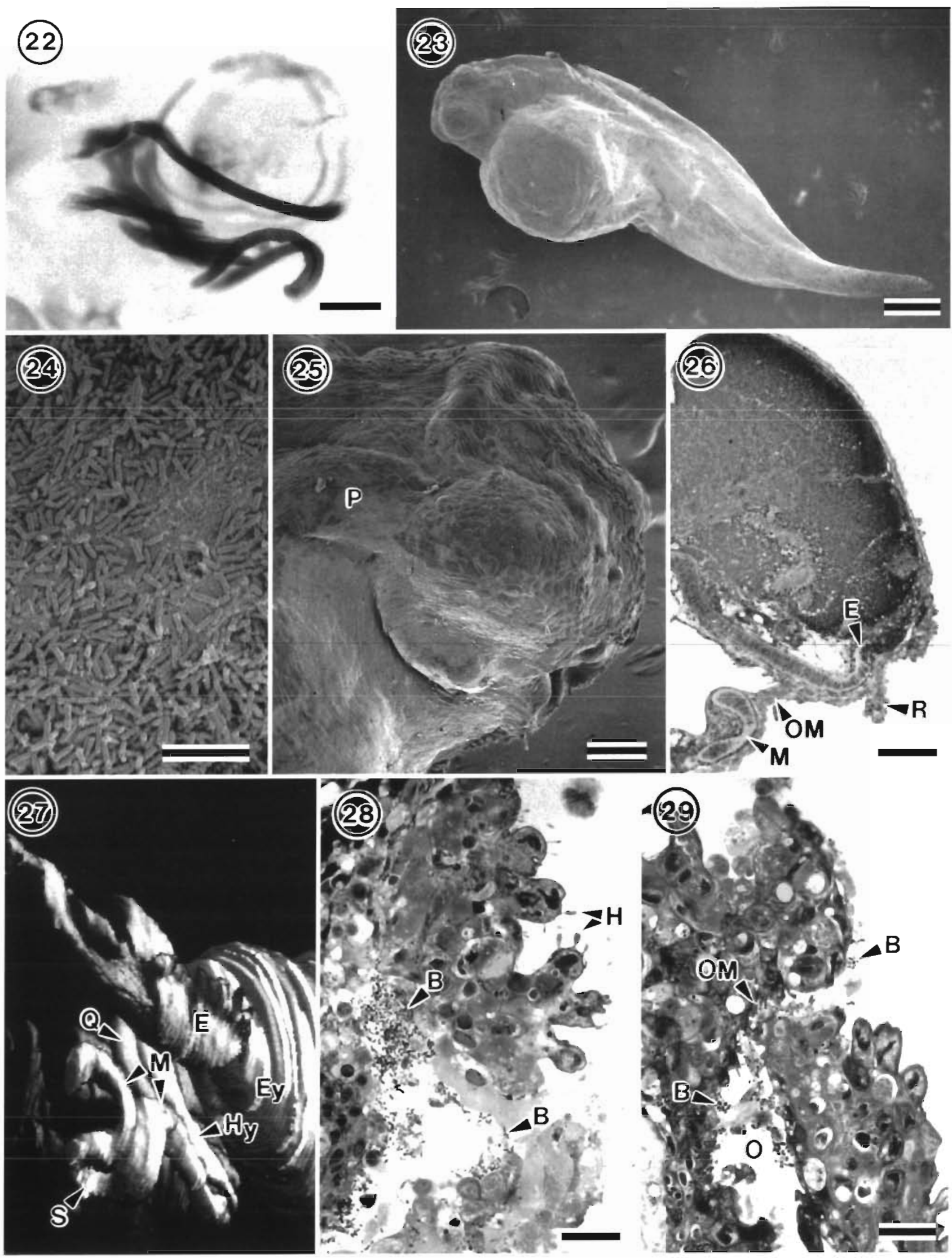


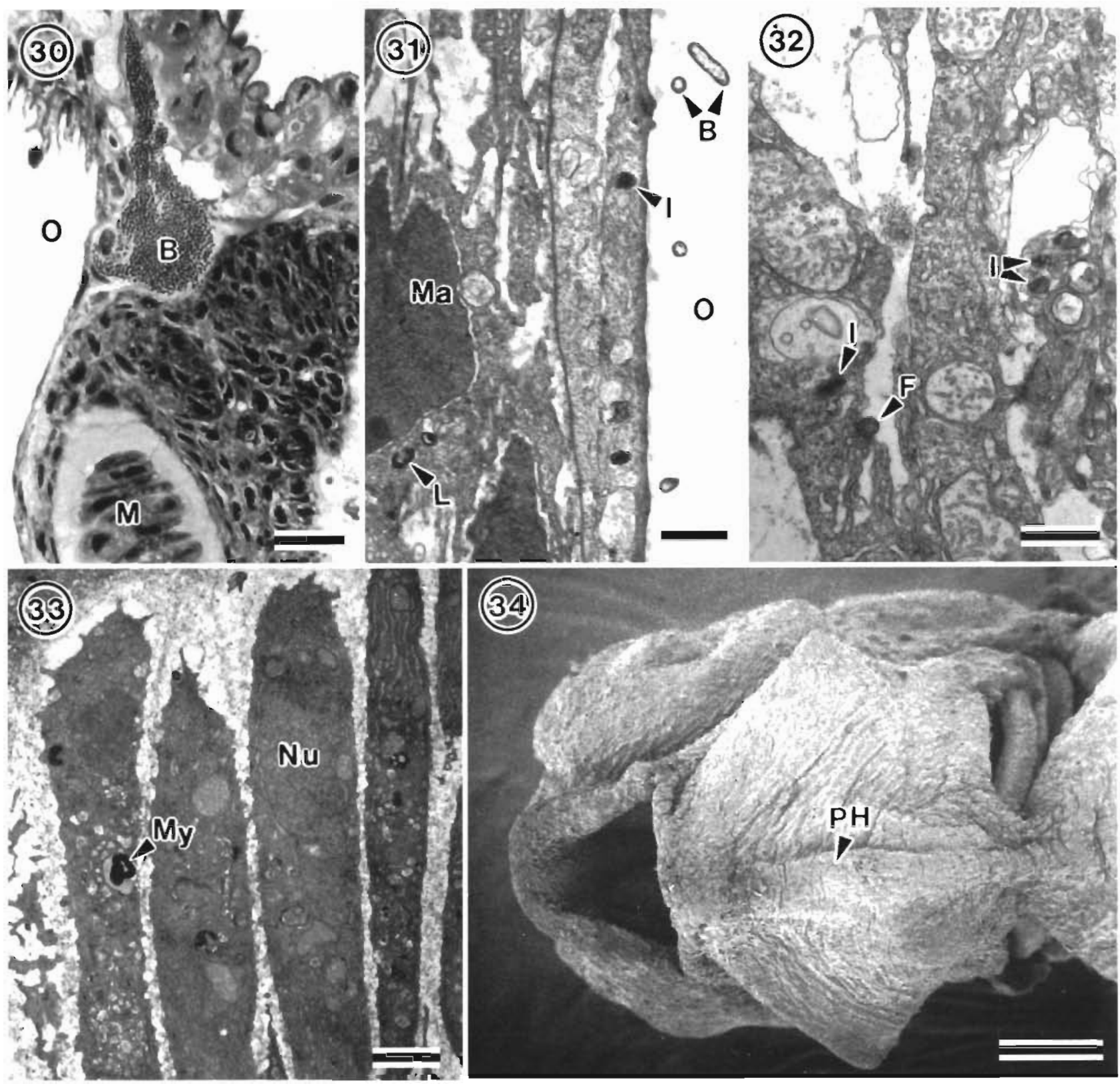

ever, membranes remained between the jaws laterally; Pittman et al. (1987) found that they persisted until yolk absorption and restricted the gape, so many larvae were seen to open and shut their mouths, apparently trying to wear away this tissue

In conclusion, the development of 'gaping jaws' appears to be related to abrasion of the head by contact with the rearing container, which should not be as significant a factor when the larvae are reared in large silos as when they are reared in small containers. It is also related to penetration of the eroded tissues by organisms present in the water, which would probably not normally be pathogenic. It should, therefore, be possible to reduce the number of larvae with this abnormality by maintaining good water quality, so that there is a low level of these organisms.

Acknowledgements. Dr K. Waiwood of the St. Andrew's Biological Station provided fertilized eggs. The Fish Health Unit of the Halifax Laboratory examined the halibut eggs for pathogenic bacteria. Dr T. Miyake, Biology Department, Dalhousie University, Halifax, read the manuscript, and helped with nomenclature of muscles and cartilages, and Dr G. Olivier, Halifax Laboratory, read the manuscript and helped with the bacteriology. Mrs Lynne Maillet, of the Electron Microscopy Unit of the Life Sciences Centre (Director Dr. I. Meinerzhagen), Dalhousie University, provided the 3-dimensional reconstruction. 


\section{LITERATURE CITED}

Austin B, Austin DA (1987) Bacterial fish pathogens: disease in. Farmed and wild fish. John Wiley and Sons, New York

Bergh $\varnothing$. Hansen GH, Taxt RE (1992) Experimental infection of eggs and yolk sac larvae of halibut. Hippoglossus hippoglossus L. J Fish Dis 15:379-391

Bergh $\oslash$. Opstad I, Pittman K, Skiftesvik AB, Skjolddal L,

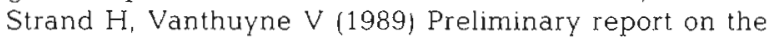
effects of temperature on the development of eggs and larvae of halibut (Hippoglossus hippoglossus) and on the bacterial population in the incubators. ICES CM 1989/F: 19

Blaxter JHS, Danielssen D, Moksness E, Øiestad V (1983) Description of the early development of the halibut Hippoglossus hippoglossus and attempts to rear the larva past first feeding. Mar Biol 73:99-107

Harboe T, Huse I, Gunvor $\varnothing$ (1994) Effects of egg disinfection on yolk sac and first feeding stages of halibut (Hippoglossus hippoglossus L.) larvae. Aquaculture 119:157-165

Harboe T, Nass T, Naas KE, Rabben H, Skjolddal LH (1990) Age of Atlantic halibut larvae (Hippoglossus hippoglossus L.) at first feeding. ICES CM 1990/F:53

Hauy T, Kjørsvik E, Pittman K (1989) Observations on a wild Atlantic halibut lava, Hippoglossus hippoglossus (L.). J Fish Biol 34:799-801

Jelmert A, Naas KE (1990) Induced deformities on larvae of the Atlantic halibut (Hippoglossus hippoglossus L.) A new experimental approach ICES CM 1990/F:45

Kjørsvik E, Reiersen AL (1992) Histomorphology of the early yolk-sac larvae of the Atlantic halibut (Hippoglossus hippoglossus L.) - an indication of the timing of functionality. J Fish Biol 41:1-19

Lonning S, Kjorsvik E, Haug T, Gulliksen B (1982) The early development of the halibut. Hippoglossus hippoglossus (L.), compared with other marine teleosts. Sarsia 67:85-91

McDowell EM (1978) Fixation and processing. In; Trump BF Jones FT (eds) Diagnostic electron microscopy. John Wiley and Sons, New York, p 113-139

Responsible Subject Editor: T. Evelyn, Nanaimo, B.C., Canada
McElman JF, Balon EK (1979) Early ontogeny of walleye, Stizostedion vitreum, with steps of saltatory development. Env Biol Fish 4:309-348

Morrison CM (1993) Histology of the Atlantic cod, Gadus morhua: an atlas. Part four. Eleutheroembryo and larva. Can Spec Publ Fish Aquat Sci 119

Opstad I, Bergh $\varnothing$ (1993) Culture parameters, growth and mortality of halibut (Hippoglossus hippoglossus L.) yolk sac larvae in upwelling incubators. Aquaculture 1099: $1-11$

Pittman K, Berg L, Naas K (1987) Morphological development of halibut (Hippoglossus hippoglossus) larvae with special reference to mouth development and metamorphosis. ICES CM 1987/F:18

Pittman K, Berg $\varnothing$, Opstad I, Skiftesvik AB, Skjolddal L, Strand H (1990a) Development of eggs and yolk sac larvae of halibut (Hippoglossus hippoglossus L.). J appl Ichthyol $6: 142-160$

Pittman K, Skiftesvik AB, Berg L (1990b) Morphological and behavioural development of halibut Hippoglossus hippoglossus L. larvae. J Fish Biol 37:455-472

Pittman K, Skiftesvik AB, Harboe T (1989) Effect of temperature on growth rates and organogenesis in the larvae of halibut (Hippoglossus hippoglossus L.). Rapp P-v Réun Cons int Explor Mer 191:421-430

Prince EE (1916) Notes on the egg and larval stages of the halibut. Sessional Paper No 38a, Contr Can Biol 15: $1.9-23$

Thompson WF, Van Cleve R (1936) Life history of the Pacific halibut. (2) Distribution and early life history. Report of the International Fisheries Commission, Number 9, Seattle

Trumble RJ, Neilson JD, Bowering WR, McCaughran DA (1993) Atlantic halibut (Hippoglossus hippoglossus) and Pacific halibut (H. stenolepis) and their North American fisheries. Can Bull Fish Aquat Sci 227:1-84

Walters GR, Plumb JA (1978) Modified oxidation/fermentation medium for use in identification of bacterial fish pathogens. J Fish Res Bd Can 35:1629-1630

Manuscript first received: August 9, 1994

Revised version accepted. February 24,1995 